\title{
Obituaries
}

\section{Ivan James Nurick}

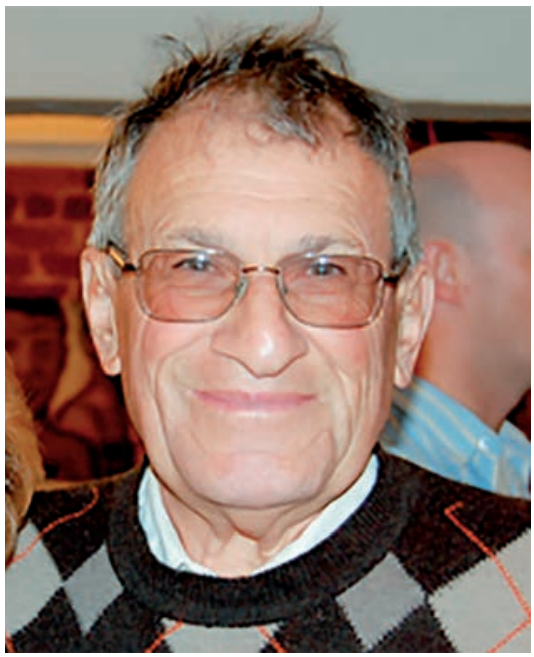

Dr Ivan J Nurick was born on 25 August 1934 in Queenstown, after which his family moved to Indwe in the Eastern Cape.

In 1952, when I arrived at Driekoppen (Belsen) residence at the University of Cape Town (UCT), the first person I ran into was Ivan and our long friendship began. We later both moved into the Medical Residence. We both married in 1959, within weeks of each other, and spent two years at Edendale Hospital outside Pietermaritzburg.

Ivan returned to Cape Town where he had a stint in general practice, but went on to specialise as an anaesthetist, training at Groote Schuur Hospital. He practised as a specialist anaesthetist until he retired in June 2008, due to ill health.

Always interested in the running of his alma mater, he achieved a variety of positions on committees. He was elected to the Student Representative Council (SRC) and the Medical Students Council (MSC), as well as the National Union of South African Students (NUSAS). He had the honour of being awarded the Abe Bailey Scholarship in 1957 and there is no doubt that he treasured this proud achievement, which took him to the UK along with other recipients of this award from other universities in South Africa.

He knew all the initials, and full names, of our class of 1957 (and those of all the directors and CEOs of share companies on the Johannesburg Stock Exchange, one of his great interests).

He was a keen facilitator of our class reunions. He enjoyed playing detective, tracing classmates wherever they were in the world, taking great pride in tracking them down, and somewhat annoyed if he received a poor response to his letters.

$\mathrm{He}$ was a keen sportsman, attending virtually every 1st Team UCT rugby game for more than 50 years. He wrote two books on the history and personalities of UCT rugby, and was also an ardent supporter of UCT cricket. He was a keen long-distance runner, and ran the Medical 10 a number of times. Ivan's interests were broad and varied: he loved opera, restaurants and cats (his beloved cat, Chelsea, was named after his favourite soccer team). He read newspapers from everywhere, national and international; he loved history, especially Jewish history, and gave talks locally on the subject, particularly on the Anglo-Boer War. He was interested in politics - local, Israeli and American. His Afrikaans was erudite and of an academic quality, and he read Die Burger every day for more than 50 years. Latterly, Ivan did courses in history and anti-Semitism at UCT, and loved being back at varsity.

A deeply spiritual man, he practised his religion honourably. He loved attending synagogue services, and also felt it incumbent upon him to attend funerals, prayers and consecrations, even when he knew the families only slightly.

His health deteriorated in 2008, and after a long struggle with his illness, he passed away quite suddenly on 29 November 2013.

We wish his wife, Shirley, and his sons Matthew, Phillip and Gideon and their families, a long life. I, personally, will miss my best friend very much.

\section{Basil Michaelides}

Retired physician

tpepler@melbro.co.za

\section{Hessel Utian}

Hessel Utian was born on 18 February 1932 and passed away on 26 February 2012.

After matriculating, at the age of 16 years, from Jeppe High School for Boys, Hessel enrolled at Wits Medical School, graduating with an MB BCh in 1954.

Having completed his junior training, he went to the UK for two years, during which time he obtained a DCH (RCP, London) and an MRCP (Edinburgh), gaining experience in paediatrics at the then Hospital for Sick Children, Great Ormond Street, London.

On his return to South Africa in 1959, he was appointed as a registrar in paediatrics at Transvaal Memorial Hospital for Children (TMHC). After registration as a paediatrician with the then South African Medical and Dental Council (now the Health Professions Council of South Africa), he joined the private practice of Drs Seymour Heymann and Sam Javett in 1962, continuing as a part-time consultant in paediatrics at TMHC, with attendance at the Cardiac Clinic and one of the general paediatric units.

In 1972, he was elected an FRCP (Edinburgh). His long association with the Department of Paediatrics, Wits University, was recognised in 1988, when he received a certificate from the vice-chancellor and principal of Wits University for 25 years of dedicated service. The Wits connection was maintained for another 25 years! Latterly, he was in charge of a special outpatient clinic that dealt with rheumatoid arthritis and other autoimmune diseases.

$\mathrm{He}$ also lectured to nurses undertaking postgraduate training for their diplomas in paediatrics, and served as examiner for the FCPaed (SA) and for the final-year medical student examinations.

Hessel was regarded as an astute clinician and will be fondly remembered by staff of the Department of Paediatrics.

At his home, he grew roses and, when they flowered, would arrive for a ward round with a beautiful rose proudly pinned to his lapel.

Our condolences go to his wife Norma (Diploma in Occupational Therapy, Wits, 1958), his four children and eight grandchildren.

\section{Solly Levin}

Emeritus Professor of Paediatric Cardiology, Faculty of Health Sciences, University of the Witwatersrand, Johannesburg, South Africa solcynth@yebo.co.za 